Article

\title{
Benjamin's Profane Uses of Theology: The Invisible Organon
}

\author{
Francisco Naishtat ${ }^{1,2}$
}

1 Instituto de Investigaciones Gino Germani, Facultad de Ciencias Sociales, Universidad de Buenos Aires, Uriburu 950,6² Piso, Ciudad de Buenos Aires C1114AAD, Argentina; fnaishtat@gmail.com; Tel.: +5411-4508-3815 or +5411-4899-5400

2 Member of the Carrera del Investigador Científico (CIC), Consejo Nacional de Investigaciones Científicas y Tecnológicas (CONICET), Godoy Cruz 2290, Ciudad de Buenos Aires C1425FQB, Argentina

Received: 24 October 2018; Accepted: 27 January 2019; Published: 2 February 2019

\begin{abstract}
Invisible, but suggestive and fruitful; deprived of any reference to doctrine or ultimate assertive foundations, but nevertheless used in Benjamin like written images, crystallized as "images of thought"; as doctrinally mute as it is heuristically audible, Benjamin's use of theology reminds us of the ironical use that Jorge Luis Borges himself made of theology and metaphysics as part of his own poetic forms. As such, these images of thought are located both in the place of philosophical use and in the one of methodological cunning or Metis, across the various levels of the corpus: a metaphysics of experience, literary criticism, philosophy of language, theory of history and Marxism. Therefore, accepting that criticism (Kritik) is the visible organon and the object of Benjaminian philosophy, is not theology, then, its invisible organon? What seems to be particular to Benjamin, however, is the agonistic but nevertheless heuristic way in which he intends to use theology in order to upset, disarray, and deconstruct the established philosophy, and specially its dominant trends in the field of the theory of history: historicism, positivism, and the evolutionary Hegelian-Marxist philosophy of history. In this article we try to demonstrate how this theological perspective is applied to a Benjaminian grammar of time. We conclude agonistically, confronting the resulting Benjaminian notion of historical past against Heiddeger's own vision of historical time.
\end{abstract}

Keywords: invisibility; heresy; disguise; disruptive; Marxism; messianism; historical time; past; redemptiveness; language

\section{Introduction}

Hannah Arendt wrote that Benjamin felt more attracted to theology than to religion, even though he "was no theologian" (Arendt 1969, p. 4). There is in Benjamin, in fact, a productive use of theological images which deviates from the conventional context of the history of religion, but which injects theology into his thinking as an antidote to the conformist and "bourgeois" 1 worldview of his time and to their respective academic ideologemes. The figures of hell, paradise, fall, guilt, eschatology,

1 Benjamin early on contrasted "the mystical" with "the bourgeois" (bürgerlichen Ansicht): in his 1916 essay on the philosophy of language, he opposed in fact the "mystical theory of language" (mystische Sprachstheorie) to the "bourgeois theory" of language (GS-II.1, p. 150). Shortly afterwards, in the Theological-Political Fragment (1921-1922), he states that the relationship between the Messianic (das Messianische) and the profane (das Profane) "is one of the essential teachings of the philosophy of history. It is the precondition of a mystical conception of history" (mystische Geschichtsauffassung) (GS-II.1, pp. 203-4 and SW-3, p. 305). Both his reflections on language and those on history already reveal the sharp edge noted by Benjamin in theology as an intensity factor agonistically inscribed against conformism (we will hereafter call GS the Gesammelte Schriften, the title of Walter Benjamin's complete works (7 volumes, 14 books), edited by Rolf Tiedemann and Hermann Schweppenhäuser in Suhrkamp, Frankfurt am Main, (Benjamin 1972-1991). Volumes are referred to in Roman numerals; books, when more than one, after a full stop in Arabic numerals; and we will indicate the page(s), after a comma, in Arabic 
creation, redemption, last judgment, Adam, Messiah-to cite but the most important ones in the Berlin-born philosopher's oeuvre-are recurrent in his work. While theology does not appear in the Benjaminian corpus as a thematic section, it nevertheless permeates the whole of Benjamin's oeuvre, spreading throughout regardless of themes or explicit references.

Thematically or from a doctrinal point of view, however, his theology is invisible. This 'invisibility' of theology in Benjamin does not mean the invisibility of the theological marks, which are on the contrary disseminated throughout the entire corpus. Therefore the expression 'theological invisibility' must be taken here with some caution; it paradigmatically refers to different figures:

(a) The well-known conclusive formula of the first thesis from On the Concept of History, where Benjamin prescribes that historical materialism "enlists the services of theology, which today, as we know, is small and ugly and has to keep out of sight" (nicht darf blicken lassen) (GS-I.2, p. 693; SW-4, p. 389). Adorno, commenting on this fragment soon after Benjamin's death, wrote in a letter to Horkheimer that "theology cannot enter as such in the written text because its 'invisibility' has become the hallmark of its truth" (die Theologie nicht in den geschrieben Text einzugehen, da ihr 'Unsichtbarwerden' heute zum Kennzeichen ihrer Wahrheit geworden ist) (Letter from Adorno to Horkheimer of September 4th 1941, quoted in (Pangritz 2000, p. 819)).

(b) This sort of cryptical invisibility is well depicted in Benjamin's famous declaration on his relation to theology (PW N7a7; Benjamin 1999, p. 471). By way of comparing theology with ink, and his own thinking with the blotting pad, Benjamin emphasizes that the latter is saturated with the former, but he observes, nevertheless, that "were one go by the blotter, however, nothing of what is written would remain" (nichts, was geschrieben ist, übrig bleiben). Therefore his standpoint is that whereas the traces of theology indeed fully impregnate his thinking, theology survives in the latter only at the prize of being completely reshaped, reminding us the beautiful title by Irving Wohlfahrt in a paper on Benjamin: "Re-Fusing Theology", not of course as a refusal of theology but as re-fusing, namely fusing it again and on a different basis with his thinking itself (Wohlfarth 1986, pp. 3-24).

(c) This figure leads us to a third plane of invisibility which is the one of the Kabbalah: in his Erinnerungen (Memories), Max Rychner pointed out that Benjamin told him that "only someone familiar with the Kabbalah-the sacred texts of the Jewish mystical tradition-could understand the notoriously difficult of the "Erkenntniskritische Vorrede" or "Epistemo-Critical Prologue" to his Origin of the German Trauerspiel" (Wolin 1994, n. 7, p. 286). Furthermore, in his dedication to Gershom Scholem's personal copy of the Trauerspiel, Benjamin wrote "Donated to Gerhard Scholem for the ultima Thule of his Kabbalah library" (Scholem 1975, p. 158). Indeed, as early as in 1918, in On the Program of the Coming Philosophy (SW-1, pp. 100-10; GS-II.1, pp. 157-71), Benjamin promoted the abandonment of the enlightened mathematical-mechanical conception of knowledge in favor of a linguistic-critical method based on the philosophy of language. But precisely his philosophy of language, developed since 1916 in his essay "On Language as Such and on the Language of Man" (SW-1, pp. 62-74; GS-II.1, pp. 140-57), so important for Benjamin's thought, is rooted both in the scriptural Jewish tradition and in the tradition of the Kabbalah. A technique of allegory and paradoxical sense, which will later shine in the Trauerspiel book, already finds all its space in the previous decade, in terms of a linguistic articulation between the sacred and the profane that can be neither self-evident nor transparent, but esoteric and fragmentary.

Therefore, it makes no sense to seek to reconstruct, against the background of Benjamin's fragmentary thinking, a visible and explicit theological core that may provide an ultimate interpretation or foundation that are lacking in philosophy. Theology in Benjamin is neither an all-encompassing key of unity, or a concealed integration of meaning, nor a content of hope capable of offsetting, like a religious counterbalance, his intellectual pessimism. However, on the other hand, there are

numerals. For the English edition of the work, we will, unless otherwise specified, refer to the one edited by Michael Jennings, in four volumes, in the Belknap Press of Harvard University Press, Cambridge, Massachusetts, 1999-2003, named Selected Writings, and we will abbreviate SW, indicating the volume with Arabic numbers, followed by the pages' numbers. 
theological motifs and references scattered throughout his oeuvre. How then should we read this relationship between the corpus and theology? How is the "task of the critic" 2 articulated with this disguised theology once we have dismissed the view of a theological basis of the work? The answer, if any, is not simple or paradox free, as shown in the already-mentioned passage of the Passagen-Werk (Konvolute N7a, 7):

My thinking is related to theology as blotting pad is related to ink. It is saturated with it. Were one to go by the blotter, however, nothing of what is written would remain (nichts, was geschrieben ist, übrig bleiben). (PW N7a7; Benjamin 1999, p. 471).

Invisible, but at the same time impregnating and fruitful; deprived of any reference to doctrine or ultimate truth, theology seems to be in Benjamin an implicit organon-namely, an implicit heuristics of thought-simultaneously located in the place of philosophical use and of methodological cunning or Metis across the various levels of the corpus: a metaphysics of experience, literary criticism, philosophy of language, theory of history and Marxism. If theology does not belong to a religious interpretation, as it would happen with a theological hermeneutics of the corpus-which seems, in our opinion, inappropriate here ${ }^{3}$ - it is however seen in Benjamin's uses of language and frameworks of thought. As stated by Günter Hartung (Hartung 2001, p. 424) ${ }^{4}$, Benjamin's Messianism and theology do not define contents of faith or of religious doctrine, but contents of thought. The latter should be captured in the modes, allegorizations (Sinnbilder) and images (Denkbilder) that constellate the Benjaminian fragments.

In his above-mentioned first thesis of On the Concept of History (1940), Benjamin, inspired by Poe's short story about the chess-playing automaton, suggests placing theology "at the service" (Dienst) of the "puppet called 'historical materialism"':

One can imagine a philosophic counterpart to this apparatus. The puppet called "historical materialism" is to win all time. It can easily be a match for anyone if it enlists the services of theology, which today, as we know, is small and ugly and has to keep out of sight. (GS-I.2, p. 693; SW-4, p. 389)

Benjamin, like Kant in his 1793 text on religion (Kant 2008), inverts here the ancilla formula that defined the relationship of theology with philosophy in medieval tradition (philosophia ancilla theologiae- "philosophy the servant of theology"). However, while in Kant the practical use of religion visibly and expressly provides a dimension of intentional hope that opens a horizon of intentional meaning to moral duty, offering a supplement of world to the emaciated transcendental rigorism, in Benjamin, far from that, the theological use is neither explicit nor does it aim at operating as a promise in the way of future expectation. Paradoxically, instead, this use of theology in no way dilutes Benjamin's visceral pessimism or faithlessness, but rather reinforces them, as shown early on by his radical rejection of any finalistic or teleological perspective in any form: theodicy, theocracy, historicism

2 Benjamin's fragment entitled "The Task of the Critic" (1931) was only posthumously published. Let us point out that Benjamin was fond of using the term "task" (Aufgabe) for characterising a series of actions considered necessary with relation to both theoretical and political activity: we can see it in the name he gives to his famous 1923 essay on translation (Die Aufgabe des Übersetzers) (GS-IV.1, pp. 9-21), as well as in his eighth thesis of On the Concept of History (GS-I.2, p. 697), where he refers to "our task" in a clearly political sense. As for "The Task of the Critic" see (Aufgabe des Kritikers, GS-VI.1, pp. 171-72; SW-2, pp. 548-49).

3 In his letter to Gershom Scholem dated 11th August 1934, Benjamin writes: “I consider Kafka's constant insistence on the Law to be the point where his work comes to a standstill (den toten Punkt), which only means to say that it seems to me that the work cannot be moved in any interpretative direction whatsoever from there" (Benjamin 1978, Band IV, p. 479). I think that this hermeneutic self-constraint concerning the theological interpretation of Kafka, may also be valid for Benjamin's oeuvre: there is no theological interpretation, which however does not at all reduce the impact of theology on the method and the development of the contents of thought. From this last point of view, theology does not only operate as a "revelation" of writing but also as the negative of revelation or, to use a suggestive term by Danielle Cohen-Levinas, inspired by the Scholem's notion of the "nothingness of revelation", as an "irrevelation" (Cohen-Levinas 2013, p. 315).

4 Cited by Erdmut Wizisla (Wizisla 2013, p. 308). 
or the philosophy of progress, as illustrated by the Theological-Political Fragment (1920-1921) and his other youth writings up to his 1940 theses On the Concept of History. We should therefore take care not to associate the concealment of theology in Benjamin with the teleological tradition of the "invisible hand" (i.e., God's or Providence's) which characterized modern philosophy from Leibniz' theodicy to Hegel's "cunning of reason" (List der Vernunft), not to mention the immanent teleology of the market in the liberal school or the philosophy of progress in "vulgar Marxism" (vulgärmarxistische Begriff) (GS-I.2, p. 699).

Accepting, then, with Adorno that in Benjamin "the invisibility of theology has become the distinctive feature of its truth" ("da ihr Unsichtbarwerden heute zum Kennzeichen ihrer Wahrheit geworden ist") (Pangritz 2000, p. 819), what is this truth and how does it move with relation to Marxism and to philosophy in order to play the double role of "being at its service" (in ihren Dienst nimmt) and, paradoxically, of being like its living, thinking organ, that is, the one that "pulls the strings" (und die Hand der Puppe an Schnüren lenkte)? To which truth, in short, does this overshadowed inscription, proper to cabalistic graphology, correspond, "counter-writing" its marks on blotting paper, turned into a dissimulator of writing not to be shown? Accepting with Uwe Steiner, on the other hand, that criticism (die Kritik) is at the same time the organon and the object of Benjaminian philosophy, ${ }^{5}$ isn't theology, then, its invisible organon ${ }^{6}$ ? Or, if one prefers, its heretic, disguised organon, a photographic negative of philosophy, or the counterfugue to its materialistic discourse? Then, instead of clinging to a binary logic, which in the name of the "excluded third" would suppress theology for Marxism or, inversely, Marxism for theology, Benjamin would be operating with a baroque counteroffensive, consisting in simultaneously combining the two opposing fronts. ${ }^{7}$ This heretic, disguised, and invisible organon is negatively characterized:

(1) It is not metatheoretically separable, like the Aristotelian "Organon" or Descartes' "rules of method";

(2) It is not "inner life", like "thought" as an intellectual basis (Nous, Esprit, Cogito, Geist, Mind) that has distinguished dualistic gnoseology;

(3) It is not an interiority of religious faith, like a Pascalian or Kierkegaardian interiority ${ }^{8}$;

(4) It is not "Leitfaden",, a Kantian guiding thread or a Hegelian-Marxist theodicy, in a teleologically providential sense of nature or history.

5 “Kritik ist aber nicht nur Organon theoretischer Reflexion, sondern zugleich auch ihr Gegenstand” (Steiner 2000, p. 479).

6 The idea of theology in Benjamin as an organon (i.e., an "instrument" in Ancient Greek) is suggested by Wolfgang Ullmann (Ullmann 1992, p. 99), who highlights the heuristic and methodological side of theology in Benjamin, possibly inspired by Franz Rosenzweig, who saw theology as a method far more than as an object of philosophy. We could, in turn, rely on the notion of "philosophical Marranism", recently introduced by Agata Bielik-Robson (2014), to account for the type of invisibility we deem it appropriate to associate with what we intend here to call "invisible organon". It seems equally suggestive to resort to the second Wittgenstein and to his notion of grammar: in fact, theological invisibility does not work in Benjamin as a phantasmal subject or inner "interiority" as "spirit", "Geist", "Intention", "daemon", or "Intellect", but rather as a deep grammar of language and writing, under the form of a palimpsest or of a scriptural watermark, but always in use. That is why the chess-playing automaton that pulls the machine strings should not be thought of in a dualistic, substantial way as "the ghost in the machine", as Gilbert Ryle (2000) caricatures Cartesian res cogitans, but rather in the manner of the second Wittgenstein, as philosophical grammar (Wittgenstein 1958). But just like Orpheus' Eurydice, this invisible organon will be veiled and even, in order to keep the Orphic parallelism, monstrously deformed, if we try to make it visible directly as doctrine or as independent methodology, as opposed to what happens with the Stagirite's logical and methodological treatises, which commentators Alexander of Aphrodisias and John Philoponus had early grouped under the name of "organon" ("instrument").

7 Ecuadorian philosopher Bolívar Echeverría, a translator and author of several studies of Walter Benjamin, who has also developed his major research on the topic of the Baroque and the Counter-Reformation in Spanish America, makes clear precisely, within what he calls baroque ethos, a logical structure consisting in the rejection of the principle of the "excluded third" and of Aristotelian logic (Echeverría 1998, pp. 199-221). Echeverría does not, but we might well state beyond him that the simultaneous use of theology and Marxism in Benjamin would thus enter the matrix of a baroque ethos.

8 In his well-known "Epistemo-Critical Preface" to the Origin of the German Trauerspiel (1925-1928), Benjamin claims: "Die Wahrheit ist der Tod der Intention" GS-I.1, p. 216 ("Truth is the death of Intention"), deviating from the model of the reflectivity of consciousness and of interiority for the benefit of an idea of truth that can be at the same time articulated with the reality of language and with the Platonic metaphysics of ideas, as if transcending any subjective and individualising interiority.

9 "Leitfaden" (guiding thread) is the expression used by Kant when introducing his propositions aimed at making universal history intelligible, through a teleological regulating idea (Kant 1922, p. 152). 
But to these features that negatively define the use of theology we could add a clear positive attribute: theology is crucial in the creation of a grammar of time, under which, throughout the corpus, the figure of "Messianic cessation" (messianischen Stillstellung) (GS-I.2, p. 703) will be articulated; a form discovered early on by Benjamin in his youth writings, especially in Trauerspiel und Tragödie (1916; GS-II.1, pp. 133-37; SW-1, pp. 55-58), which germinates in his works as if in a spiral, crystallizing in the last five theses from On the Concept of History (GS-I.2, pp. 701-4).

\section{Results}

\subsection{Early Benjaminian Theologumena-A Technique of Crisis}

Jacob Taubes once argued that, for Benjamin and his generation, the reference of a Messianic event is no longer found at the virtual level of the regulative ideal but in the exceptional present time of the historical events they witnessed: the First World War, the October Revolution, the catastrophe of fascism (Taubes 1993). From this point of view, according to Taubes, what has been decisive in the framework of Benjaminian Messianism is the historical experience that affected his generation. Hence the arc drawn by Taubes between Benjamin's Messianism and Pauline Kairos, lies in the idea of the "(exceptional) present time", to which Taubes associates the Benjaminian notion of "now-time" (Jetztzeit) that refers to suspended or stopped time, "a present that is not transition" (einer Gegenwart, die nicht Übergang ist) (theses XIV, XVI, and XVIII, On the Concept of History, GS-I.2, pp. 701-3). ${ }^{10}$

In his early 1915 text titled "The Life of Students" (Das Leben der Studenten), Benjamin surprises us by placing the Messianic and the historical side by side, when he literally writes "Messianic kingdom or the idea of French revolution" (messianische Reich oder die französische Revolutionsidee), clarifying that it is not a "formless tendency of progress" (gestaltlose Fortschrittstendenz), but that which is "deeply rooted in every present in the form of the most endangered, excoriated and ridiculed ideas and products of the creative mind" (SW-1, p. 37). Benjamin then explains that "the historical task" (geschichtliche Aufgabe) "is to disclose this immanent state of perfection and make it absolute" (Den immanenten Zustand der Vollkommenheit rein zum absoluten zu gestalten), "to make it visible and dominant in the present" (ihn sichtbar und herrschend in der Gegenwart zu machen) (SW-1, p. 37; GS. II-1, p. 75). This passage anticipates Benjaminian inflection and reconfiguration of the Kantian figure of the endless task, which had been reappropriated by Hermann Cohen in the context of his peculiar synthesis between Kant's philosophy and Jewish Messianism, laying emphasis on the notion of hope (Cohen 1924; Abadi 2014, pp. 69-99). Benjamin will not stop settling accounts with Neo-Kantianism throughout his work. In his last thesis "On the Concept of History», Benjamin will in fact clear up the prejudices underlying the conception of time in Neo-Kantianism and in German social democracy around the notions of "ideal", "progress" (Fortschritt) and "endless task" (unendliche Aufgabe), whereby he reveals the structure of an eternal postponement.

The ideal was defined in the Neo-Kantian doctrine as an "infinite [unendlich] task" (unendliche Aufgabe). And this doctrine was the school philosophy of the Social Democratic Party-from Schmidt and Stadler to Natorp and Vorländer. Once the classless society had been defined as an infinite task, the empty and homogeneous time (die leere und homogene Zeit) was transformed into an anteroom (Vorzimmer), so to speak, in which one could wait for the emergence of the revolutionary situation (revolutionäre Situation) with more or less equanimity. In reality, there is not a moment that would not carry with it its revolutionary chance

10 At the time of the war, a certain Messianic juvenilism crossed the Atlantic without its bearers on both sides having always kept direct relationships, as if generational constellations transcended individuals: The then young Argentine philosopher, contemporary of Benjamin, Deodoro Roca, a mentor of the University Reform of Córdoba in 1918, advocated ideas that were very close to the young Benjamin's reflections in texts such as "The Life of Students" "Das Leben der Studenten", GS-II.1, pp. 75-87) and "The Metaphysics of Youth" ("Metaphysik der Jugend", GS-II.1, pp. 91-104). Roca talks in his writings of the "bankruptcy of civilization", drawing from the world crisis and catastrophe between 1914-1918 the political energies of a Liminal Manifesto with Messianic and at the same time revolutionary hints (Roca 1999, pp. 77-82; Roca 1999, p. 102). 
(revolutionäre Chance) - provided only that it is defined in a specific way, namely as the chance for a completely new problem [Aufgabe]. (SW-4, pp. 401-2; GS-I.3, p. 1231) ${ }^{11}$

But, more than two decades before that, in the fragment titled "Trauerspiel and Tragedy" (Trauerspiel und Tragödie, 1916, GS-II.1, pp. 133-37, SW-1, pp. 55-58), not published during the author's life, Benjamin had already pointed out, like in his youth writings above mentioned, the need for another grammar of time. On this occasion, the Berlin-born philosopher placed his problem on the demarcation of history, namely the singularity of historical experience and time in the semantic network of the notions of "Messianic time" (messianische Zeit) and of "Baroque drama" (Trauerspiel), thereby deviating from the paradigm of mechanical time already disqualified with the same epithets of "homogeneous", "continuous" and "empty" that he would use two decades later in his theses of On the Concept of History to refute the model of historicist time and of vulgar Marxism.

For we should not think of time as merely the measure $(\mathrm{Ma} \beta)$ that records the duration of a mechanical change (mechanischen Veranderung). Although such time is indeed a relatively empty form (relativ leere Form), to think of its being filled makes no sense (keinen Sinn bietet). Historical time, however, differs from this mechanical time. It determines much more than the possibility of spatial changes (Raumveränderungen) of a specific magnitude and regularity—-that is to say like the hands of a clock—simultaneously with spatial changes of a complex nature. And without specifying what goes beyond this, what else determines historical time-in short, without defining how it differs from mechanical time-we may assert that the determining force (bestimmende Kraft) of historical time (historischen Zeitform) cannot be fully grasped by, or wholly concentrated in, any empirical process (von keinem empirischen Geschehen völlig erfaßt). Rather, a process that is perfect in historical terms is quite indeterminate empirically; it is in fact an idea. This idea of fulfilled time (erfüllten Zeit) is the dominant historical idea of the Bible: it is the idea of messianic time. (SW-1, pp. 55-56; GS-II.1, p. 134)

This passage by the young Benjamin focuses on the understanding of historical time, and on the very characterization of history: what is it that makes an event or an experience be considered historical? This refers to the contrast with time in natural science. However, for Benjamin's demarcation of the historical, the idea of the Messianic, as noted in the conclusion of this passage, plays a key role. In fact, the historical does not lie for Benjamin in the raw empirical datum, but in the "idea", which, as Benjamin states here, is what fulfills (vollendet) the "perfect happening" (vollkommen Geschehen), saving it from the flow of "empirical events" (empirischen Geschehen). Only what the idea gathers, so to speak, makes sense from the point of view of history (im sinne der Geschichte). Later, in his famous "Epistemo-Critical Preface" (1928) to the book on the German Trauerspiel ("Erkenntniskritische Vorrede", GS-I.1, pp. 207-37), this "idea" will be understood as what "saves" (retten) the unique phenomenon and, let's say, inscribes the event in the constellation of a historical truth (GS-I.1, pp. 214-15). Therefore, we should take care not to confound this 'idea' with what the southwest Baden School of Neo-Kantian philosophy understood as "value relation" (Wertbeziehung), a subjective axiological charge that creates historicity and its meaning. Indeed, for the southwest German school of Neo-Kantianism, values are immanent to intentionality and as such belong to the historian's subjective burden, ultimately resulting in a relativistic perspectivism that will end up crystallizing with Max Weber on a Nietzschean plane of immanence, abandoning the remains of a Kantian transcendentalism that were still to be found in Rickert. For Benjamin, on the other hand, the "idea", as a Messianic figure, draws its absolute and infinite redemptive strength from a transcendent Neo-Platonic realm, radically reformulated

11 This fragment belongs to the preparatory notes for the theses On the Concept of History, the so-called "Paralipomena", and it is noted XVIII'; in fact it was discovered by Giorgio Agamben in 1975 within a typewritten version of Benjamin's theses-Handexemplär - that the Italian philosopher found among George Bataille's papers in the latter's office at the National Library in Paris (Raulet 2010, p. 172). 
through the Benjaminian notion of Constellation (Konstellation), which is one of the keystones for his "redemptive criticism" (Wolin 1994, pp. 29-77). Therefore the Messianic is already understood in the path of the historical happening (Friedlander 2012, pp. 200-1), i.e., as profane theology, creating paradoxical inversions and polarizing political and religious extremes into one another, a divide but also an allegorical articulation (Wolin 1994, pp. 29-77) between history and theology as it is indicated by Benjamin in 1921 through his Theological-Political Fragment:

The secular order (Ordnung des Profanen) should be erected on the idea of happiness. The relation of this order to the messianic (das Messianische) is one of the essential teachings of the philosophy of history. It is the precondition of a mystical conception of history (mystische Geschichtsauffassung), encompassing a problem that can be represented figuratively. If one arrow points to the goal toward which the secular dynamic acts, and another marks the direction of messianic intensity (messianischen Intinsität), then certainly the quest of a free humanity for happiness runs counter to the messianic direction. But just as a force (Kraft), by virtue of the path it is moving along, can augment another force on the opposite path, so the secular order (die profanen Ordnung des Profanen)-because of its nature as secular-promotes the coming of the Messianic Kingdom (das Kommen des messianischen Reiches). The secular (Das Profane), therefore, though not itself a category of this kingdom, is a decisive category of its most unobtrusive approach. (SW-3, p. 305; GS-II.1, pp. 203-4)

Benjamin's understanding of Messianic time, initially with an altered Platonic bias, draws therefore the line of an integral historical experience dissolving the conventional understanding of secularized history as being void of theology, and opposing to it an invisible theology of history (Bolz and Reijen 1996, p. 16), not to be confounded with theocracy. If the theocratic view of history is purposively or teleologically understood in terms of a historical realization of the Messianic kingdom, either asymptotically or effectively, Messianism is experienced by Benjamin not as a goal or future-oriented state of facts, but as an interruption of time, in terms of remembrance and translation of the past, anchored in a polarity of justice that obstructs the profane, opening a "mise en abîme" or Aktualisierung, by way of trace, ruin and spectrality (Derrida 1994, p. 165; Derrida 2002), favoring interruption (Unterbrechung), and suspension (Stillstand) of our present as well as profane illumination (profanen Erleuchtung).

\subsection{Hope in the Past ${ }^{12}$ - Towards the Notion of Messianic Time}

In order to capture the entire peculiarity of Benjamin's early understanding of messianic time, it is important to briefly address the German debate from the end of the nineteenth century and the beginnings of the 20th around the status of historiography and the Geisteswissenschaften. In fact, the problem of the uniqueness of historiography and its regional ontology had already shaken German social sciences reaching the center of the controversy known as Methodenstreit ("method dispute") which marked the epistemology of social sciences and hermeneutics, questioning thinkers of the stature of Dilthey, Windelband, Rickert, Lask, Simmel, and Weber (Oakes 1986). If for the Neo-Kantian school of southwestern Germany (Windelband, Rickert, Lask), and for Dilthey's Hermeneutics, the demarcation of history with respect to natural sciences lies at the bottom of their epistemological understanding, the criterion underlying this demarcation remains within the frame of the intentionality of consciousness. In particular, the young Heidegger, whose Habilitation dissertation was supervised by Heinrich Rickert, focused his lecture precisely on the issue of time in historiography. His lecture was titled "The Concept of Time in the Science of History" (Heidegger 2011) and was given at the University of Freiburg on 15 July 1915, that is, some months before Benjamin wrote his fragment on Trauerspiel and Tragedy (1916). At first sight, upon comparing both texts, we can see a striking

12 "Hoffnung im Vergangenen", Peter Szondi's eloquent formula to characterize Benjamin's notion of time (Szondi 1961). 
affinity between the two thinkers: namely, the express opposition of historiographical time against the "homogeneous", "mechanical", and "continuous" time of natural sciences rendered in quite analogous terms (Heidegger 1978, pp. 415-25). A more cautious look, however, reveals great discontinuities between both perspectives, and that clarifies the Messianic understanding of Benjaminian historical time. In fact, the paths of both thinkers radically fork upon confronting the ontology and knowledge of the past. To Heidegger, the "historical object" "no longer exists":

The historical object, as historical, is always past: in the strict sense it no longer exists. A temporal divide [Zeitferne] separates the historian from the past. The past has its meaning always and only when seen from the present. When viewed from our standpoint, the past not only no longer is; it also was something other than we and our present-day context of life are. This much has already become clear: time has a completely original meaning in history. Only when this qualitative otherness between past times and the present moment breaks into consciousness does the historical sense awaken $(\ldots)$.

We may say, then, that the starting point of time-reckoning manifests the principle that controls all concept formation in history (das Prinzip der historischen Begriffsbildung): relatedness to a value (die Wertbeziehung) [emphasis in the original]. (Heidegger 2011, pp. 68-72; Heidegger 1978, pp. 427-33)

Heidegger extracts from this premise two fundamental conclusions: (i) the past has meaning only in the present; (ii) this past is not for us what it was for itself (Heidegger 1978, p. 427). He thus asserts that: (iii) therefore, there is a temporal distance (Zeitferne)—even an abyss (Kluft) — between the historian and the past, which can only be covered by means of the values (Werte) of the present, namely a resolution by the historian mediated by relatedness to a value (Wertbeziehung), in a similar way to Heinrich Rickert, who had considered since 1902 the selection and knowledge of the historiographical object; (Heidegger 1978, p. 433; Rickert 1913). Thus, Heidegger's position in 1915, already moving towards the idea of temporalization in Sein und Zeit (1927), is that it is through the future-namely by means of our present value-orientation allowing historiographical selection-that it is possible to cover the historical gap between present and past. Walter Benjamin, in his letter to Gershom Scholem of November 11, 1916, commenting on Heidegger's text, points out that the Conference "documents precisely how this subject should not be treated" (Adorno and Scholem 1994, p. 82 [emphasis in original]). This brings us back again to Benjamin's Trauerspiel und Tragödie (1916), not published, as we observed above, during Benjamin's lifetime. Although setting the issue of historical time as his focal point, Benjamin nevertheless refers in this crucial early text to the consideration of death in Tragedy and death in Trauerspiel (mourning play). These forms therefore lead to two dramatic figures where the notions of erfüllt (fulfilled) and unerfüllt (unfulfilled) play a central function: while recognizing that the trajectories of tragedy and of historical time overlap-something that is grounded in the actions of heroes (SW-I, p. 55), Benjamin makes indeed a consideration that will completely take another turn: he observes that "Historical time is infinite (unendlich) in every direction (in jeder Richtung) and unfulfilled (unerfüllt) at every moment (in jedem Augenblick)" (SW-1, p. 55; GS-II.1, p. 134), and then he radically distinguishes two sorts of time-fulfillment-namely individual tragic time, and messianic historical fulfillment. Only the latter could properly lead to messianic or fulfilled historical time. Therefore, despite the above affirmation concerning the overlapping between the tragic genre and historical time, no individual or tragic fulfillment of time could by itself determine historical meaning, which instead could only be constituted through messianic fulfillment:

Moreover, the idea of a fulfilled historical time is never identical with the idea of an individual time. This feature naturally changes the meaning of fulfillment completely, and it is this that distinguishes tragic time from messianic time. Tragic time is related to the latter in the same way that an individually fulfilled time relates to a divinely fulfilled one. (SW-1, pp. 55-56). 
So, we have here two forms of time - the tragic and the messianic - that for Benjamin fit with two forms of fulfillment: the individual and the divine respectively. It seems as if the tragic, restricted to the individual plan of the hero, could neither achieve nor fulfill the historic, whose fulfillment relates to the messianic. In the second part of his text, Benjamin complicates this first sketch with the introduction of a third form, the mourning play, or Trauerspiel, as a transitional device: "the mourning play is in every respect a hybrid form" (SW-I, p. 57). The specification of this form is obtained through the contrast between two figures of death, the 'tragic' and the Trauerspiel's 'figure of death'. While the former is governed by the law of fate and corresponds to the individual fulfillment of time by the hero's death (SW-I, p. 56), the latter is governed by the law of repetition, where death is only the spectral transition to a form of continuity mediated by a mirror image, defined by Benjamin with Aristotle's 'metabasis of life' (eis allo genos) - transformation into another type or sort (SW-I, pp. 56-57). This defines Trauerspiel's 'death' as a non-conclusive death. It means that Trauerspiel corresponds to a form of expansion and dissemination (SW-I, p. 57) that is typical not only of baroque time, but of modern time, as one which lacks meaning and conclusiveness, and as a time of desolation and dissolution (Caygill 1994; Sagnol 2003). In front of that it is not the tragic fulfillment of the individual heroic death that will carry out the restoration of historical meaning, but the messianic fulfillment belonging to the historical rescue itself. This messianic time however is not literally visible in the Trauerspiel but only allegorically indicated by way of the allegorist's work of art. Ultimately, the messianic is not visible at first sight but only through redemptive criticism. As such, it belongs to the Afterlife (Nachleben) of the play (Sagnol 2003, p. 53; Wolin 1994, pp. 29-77). It is as if the messianic, from then on, remained for Benjamin a keystone, at the top of his earliest phases but not least of the latest context of his thesis On the Concept of History (1940), moving on to counterbalance, through a theological plane of redemptive criticism (rettende kritik) (Habermas 1972; Wolin 1994, pp. 29-77), the hermeneutics of meaningful individual heroes and future-oriented subjectivity.

Heidegger for his part did not publish anything between 1916 and 1927, year of the edition of his magnum opus, Time and Being (Sein und Zeit-SuZ, Heidegger 2006) whose second section is dedicated to the temporalization of Dasein and where he reformulates his approach to historical time further distancing himself from the epistemological context of his work of 1915. In Sein und Zeit, Heidegger distinguishes the past as 'ontic', meaning a time that would simply be a 'succession of nows' (Jetzfolge), from a past that Heidegger calls 'ontological', as being reflexively maintained in the present of oneself through its own moving towards the future, for a self that temporalizes itself into the projection that Heidegger calls Ekstasis - being at the same time its own past and anticipating its future, but in a way that being projected (Entwurf) is the possibility of gathering its own time. Here, Heidegger takes from Wilhelm Dilthey the expression "connection of life", (Zusammenhang des Leben) for this maintenance of the past in the present under the possibility opened through projection. Like Giorgio Agamben said (Agamben 1978), Heidegger's originality is to propose historical time from the assumption of the temporalization of Dasein, and the latter through the figures of resoluteness (Entschlossenheit) and instant (Ekstasis), as attached to the same being of Dasein. Then, the figures of Zeitigung and Entschlossenheit are linked to the care (Sorge) and authenticity (Eigentlichkeit) of the figure of being-towards-death (Sein zum Tode), which is the keystone to the projectivity of Dasein. We exist towards death, and that allows us to live our past as being from birth to death within the structure of finitude. For Heidegger death is not an event: it is a phenomenon that must be understood existentially (SuZ, p. 251). The issue of death lies at the core of temporalization, and therefore, of Heideggerian historicality-something that Adorno criticized in his famous The Jargon of Authenticity (Adorno 1973). Being-towards-death is for Heidegger inherent to the Geworfenheit, of our being thrown and our finitude as facticity. The authentic choices of Dasein projected in a singular destiny (Schicksal) are interwoven in order to form the fate (Geschick) of a people (Volk). The coincident interweaving of fates finds its locus in the figure of generation (Generation). Some scholars agree nevertheless that there is a vagueness and incompleteness in the term Generation used by Heidegger (Barash 2003, pp. 170-73). Indeed, we wonder here about the gap that Heidegger crosses in the second Section of 
Sein und Zeit, by moving without a sentence from the level of individual existence to the plane of historical collective sociality, namely the Volk, or the Generation, precisely in relation to matters such as past, future, and the pole of death. Actually, the collective level does generate a structural asymmetry in relation to an anthropological reality such as death. There is a tale by Kafka named "An Imperial Message" (Kafka 2009) that Benjamin selected during his radio shows on the Czech writer (GS-II.2, pp. 676-83), in which a messenger is summoned to the Chinese emperor's deathbed. The prominent court men around the emperor open his way and the emperor whispers a secret in his ear-words that no one else hears-and asks him to transmit those very same words to someone who awaits the message on the other side of the empire. After saying these words, the emperor dies. The Chinese messenger's dread is proportional to the immensity of his urgent task due to the fact that just to leave the capital of the empire he must go through countless human barriers composed of the subjects of the crown that are there to be with the emperor during his last breath. The difficulties multiply as the messenger tries to open his way and he soon realizes that he will never be able to personally deliver the message to its receiver. Concerning this story, we could think about the problem that has often been ignored by hermeneutic tradition: the problem of the danger surrounding transmission, and therefore the main task of rescuing the message inherent to its transmission, transmissibility, and linguistic revelation. After all, the god Hermes, out of whom Hermeneutics takes its name, was a messenger. Transmission, transmissibility, and linguistic revelation are always for Benjamin threatened and in danger, and the task of interpretation belongs to the dimension of survival and Afterlife (Nachleben) of rescuing and saving (Rettung) an oppressed tradition whose transmissibility and revelation demands to "brush history against the grain" (die Geschichte gegen den Strich zu bürsten) as it is concluded in the Thesis VII in On the Concept of History (GS-I.2, p. 696; SW-4, p. 392). Therefore, while in Heidegger, under a tragic perspective, the main issue of the finite historicality is destiny, marked through the death pre-orientation of Dasein, in Benjamin it is not destiny but danger that is the main condition surrounding transmission and interpretation which are always under the threat of disappearance or mythical disfiguration; and the answer to danger is not the epic authenticity of the hero who resigns in silence to destiny, but the interruption of destiny in terms of a messianic break through our experience with past and remembrance. The threat against transmission may be each time dismantled in Benjamin through the figures of rescue (Rettung) and Afterlife (Nachleben), as the creatural and profane plane of experience and language, therefore not as Erlebnisse or inner states of consciousness, but as Erfahrung or transindividual experience, like constellated instances and monades that are heterogeneous, yet at the same time articulated and scattered in a mesh of experiences in time that relate to the translation of different languages, the rescue of different strata of time, and the different disposals and ruins from the past that claim to be rescued through language by commentary, criticism, translation, remembrance, and revelation at the core of Benjaminian profane figures of theology and interpretation.

This is the way in which Benjamin pursued his research beyond his early production of the years 1913-1916: trying to think of a decentralized notion of experience based on transmission rather than on inner-consciousness; on languages and translation rather than on authenticity and selfhood; and on materials and ruins in danger, rather than on heroes and destiny. In this sense, it is with the notion of "remembrance" (Eingedenken, according to the neologism introduced by Benjamin himself) that there emerges at last a Messianic grammar of the time of history and a relational conception of the past opposed to the axiological presentism of intentionality. Remembrance is not simply a layer of the intentional consciousness, but it is made up of the involuntary memory, dream contents and the moment of its recognizability (Augenblick seiner Erkennbarkeit, GS-I.2, p. 695; SW-4, p. 390) that combine with the reflective work inherent in Eingedenken. Hence, remembrance is telescoping of the past through the present, so that it is more a "translation" of the past into the present (Friedlander 2012, p. 198) than a mere repetition based on the identity of memory contents susceptible of empathic experience, like the one we can see in the Einfühlung tradition, proper to Dilthyian Geisteswissenschaften. But to speak here of translation is consistent with the fact that Benjamin, like early romantics, views the epoch as a text (Bolz and Reijen 1996, p. 5), and its interpretation as the experience of being able 
to read what has never been written, as Benjamin wrote after Hofmannsthal in his fragment On the Mimetic Faculty (SW-2, p. 722). Needless to say, we can bridge this textual and reading paradigm to the Kabbalistic tradition of commentary and Haggadah, more made up of anecdotes and stories of the rabbinic literature than of the direct teaching of the Mosaic Law (Halakhah)—difference that was crucial for Benjaminian's interpretation of Kafka's literature (SW-II.2, p. 679; SW-2, p. 496; Br VI-1938-1940, p. 113). Therefore, through this figure of Eingedenken, Benjamin introduces an entirely original idea of the past, as something persistent in the present and, contrary to Heidegger, totally irreducible to intentionality, as follows from the early Benjaminian assertion that "Truth is the death of intention" (Die Wahrheit ist der Tod der Intention) (GS-I.1, p. 216). However, along the path of the assertion of this unfinished past, Benjamin not only confronts Heidegger, but also Horkheimer, whose letter dated 16 March 1937 Benjamin recalls in the following fragment of The Arcades Project (Das Passagen-Werk):

On the question of the incompleteness [Unabgeschlossenheit] of history, Horkheimer's letter of 16 March 1937: "The determination of incompleteness [Unabgeschlossenheit] is idealistic if completeness [Abgeschlossenheit] is not comprised within it. Past injustice has occurred and is completed [abgeschlossen]. The slain are really slain... If one takes the lack of closure [Unabgeschlossenheit] entirely seriously, one must believe in the Last Judgement ... Perhaps, with regard to incompleteness [Unabgeschlossenheit], there is a difference between the positive and the negative, so that only the injustice, the horror, the sufferings of the past are irreparable [irreparabel sind]. The justice practiced, the joys, the works, have a different relation to time, for their positive character is largely negated by the transience of things [wird durch die Vergänglichkeit weitgehend negiert]. This holds first and foremost for individual existence [im individuellen Dasein], in which it is not the happiness but the unhappiness that is sealed by death".

(Das Passagen-Werk, Erkenntnistheoretisches, Theorie des Fortscritts, [N 8, I]); (Benjamin 1999, p. 471).

Benjamin's answer to Horkheimer follows immediately in the same fragment, but here theology jumps to the forefront through the very movement of remembrance:

The corrective to this line of thinking may be found in the consideration that history is not simply a science but also and not least a form of remembrance [eine Form des Eingedenkens]. What science has "determined" ["festgestellt"], remembrance can modify [kann das Eingedenken modifizieren]. Such mindfulness [Eingedenken] can make the incomplete [das Unabgeschlossene] (happiness) into something complete [Abgeschlossenen], and the complete [Abgeschlossene] (suffering) into something incomplete [Unabgeschlossenen]. That is theology [Das ist Theologie]; but in remembrance [im Eingedenken] we have an experience [Erfahrung] that forbids us to conceive of history as fundamentally atheological [atheologisch zu begreifen], little as it may be granted us to try to write it with immediately theological concepts [so wenig wir sie in unmittelbar theologischen Begriffen zu schreiben versuchen dürfen].

(The Arcades Project, N, On the theory of Knowledge, Theory of Progress, [N 8, I]; Das Passagen-Werk, Erkenntnistheoretisches, Theorie des Fortscritts, [N 8, I]); (Benjamin 1999, p. 471).

In this exchange, whose importance we cannot overestimate, not only does Benjamin cast a line separating history and science through the function of remembrance (Eingedenken), as the corner stone of history, but he advocates for the understanding of remembrance in terms of theology, and nevertheless the use of theology in history, not through "immediately theological concepts" (unmittelbar theologischen Begriffen). What is then this use of theology forbidding the "immediately theological concepts"? This is what Theodor Adorno, in a letter to Benjamin of 17 December 1934, commenting on Benjamin's essay on Kafka of that year, has named "the coded character of 
our theology" (Chiffernwesen unserer Theologie), recognizing that "the image of theology in which I see with pleasure that our concepts are hidden is none other than the one that spice up your thoughts", and declaring that "it can be called Inverse Theology" (es mag wohl "inverse Theologie" heißen) (Adorno and Benjamin 1994); it is also worth on this topic of the Adornian inversed theology to see (Bolz and Reijen 1996, pp. 13-20) and (Pangritz 2000, pp. 788-89). Somehow we anticipated above this figure of inversed theology both with the device of theology's invisibility, through the figure of the "hunch backed dwarf" (buckliger Zwerg), concealed master of chess on the first thesis of On the Concept of History (GS-I.2, p. 693; SW-4, p. 389), and the function of Haggadah, opposed by Benjamin to Halakhah in the Benjaminian interpretation of Kafka (SW-II.2, p. 679; SW-2, p. 496; Br VI-1938-1940, p. 113), namely through the total Benjaminian transposition and reshaping of the theological motives into the profane realm. Moreover, the movement of remembrance (Eingedenken), as theologically articulated, is condensed both as what makes history irreducible to science, and as what opens the "chamber of the past" (GS-I.3, p. 1231; SW-4, pp. 401-2). The past bears in itself a demand (Anspruch) which we can take up from the present inasmuch as we have been endowed with a "weak Messianic power" (schwache messianische Kraft) (GS-I.2, pp. 693-94; SW-4, p. 389).

\subsection{Theology of History and Theology of Language: Rescuing in Translation}

There is an "experience with the past", that should not be understood as a direct or immediate theological writing of history but as an indirect theological method, inasmuch as "method is detour" (Methode ist Umweg), as affirmed by Benjamin in his Erkenntniskristische Vorrede to the Ursprung des deutschen Trauerspiels (GS-I.1, p. 208). Then the paradigm of translation, drawn from Benjamin's philosophy of language, can help us understand this relationship between present and past: it is not about repeating or reviving an identical past through empathetic identification with it but about "translating" past into the present, so that, in being reconfigured in translation it breaks in the present offering us a disruptive experience through revelation in language. But, unlike the unilateralism of the intentional relationship established by the value paradigm (Wertbeziehung), the translation paradigm must rely on otherness and maintain with it a relationship that is not egocentric, seeking to save in one's own language the foreign ground where it encounters and receives otherness. But such disposition, in Benjamin, is theological since it stems from the common loss in one's own language and in the foreign language of the original pure language. It is therefore through shared absence and loss and not through community sameness and community identity that the translatability of secular languages (Übersetzbarkeit) appears in Benjamin as the primordial linguistic fact through the possibility of a rescue and redemption of otherness (GS-IV.1, pp. 9-21). Analogously, it is the Benjaminian inachievement (Unvollendung), incompleteness (Unerfüllen) and inconclusiveness (Unabgeschlossenheit) of the historical past (GS-II.1, pp. 133-37; PW N8,1), actualized in the spectral and undeconstructible idea of "past claim" (Anspruch) (GS-I.2, p. 694) (Derrida 1994, pp. 35-40) that the community of experience between past and present is possible. This spectrality, always exceeding law and history, is neither a regulative telos nor a "reified" realization of justice, but always an opening and an excess of now-time (Jetztzeit) itself (SW-4, pp. 401-2). Toward the end of his On the Program of the Coming Philosophy (1918), Benjamin places religious experience and the philosophy of language next to each other, at the same time positioning both of them in the trail of Johann Georg Hamann (1730-1788), Kant's contemporary and rival, precursor of the Sturm und Drang. However, in a text written just before the "Program", namely, On Language as Such and on the Language of Man (1916) (GS-II-1, pp. 140-57) Benjamin had already drawn from Hamann and Genesis a naming theory of the origin of languages and a concept of man's exit from paradise as the loss of the original language and the decline of languages (based on the biblical legend of Babel), which then give up their rescuing role of Adamic naming to adopt a merely communicational, instrumental role. Here Benjamin opposes communication "through a language", giving rise to what he calls "the bourgeois theory of language", to communication "in a language", leading to what he calls "the mystical theory of language", raising the latter, non-instrumental figure, to the rank of "the linguistic being of things", and of the "spiritual essence of man". The biblical event 
of the fall and the expulsion from paradise hence appear in the treatise on philosophy of language as the key step since it is connected not only with the proliferation of languages based on communicating "something", and the concomitant notion of "chatter" (Geschwätz) (GS-II.1, p. 153) taken here from Kierkegaard, as language degraded by guilt, good and evil, or losing oneself in the frenzied world of the reification of language, but also, on the flipside, with the idea of translation-Übersetzung —and "translatability" (Übersetzbarkeit), as the (possibility of) restoration of the original language trace: "translation attains its full meaning in the realization that every evolved language (with the exception of the word of God) can be considered a translation of all the others (GS-II.1, p. 151 et seq.). Also, through this relationship of languages as a center of varied thickness: Benjamin says, "the reciprocal translatability between languages takes place." Subsequently, this reappears through a philosophy of translation in his famous text The Task of the Translator (1923) (GS-IV.1, pp. 9-21). Here the Jewish theological image of the Tikkun is key: this element, which in Lurianic Kabbalah refers to a shattered vessel that claims restoration, is the figure of the restitution of harmony to the world. In Benjamin's view, the task of the translator is not to conquer the foreign language by assuming that there is a common sense beyond linguistic difference, but to penetrate one's own language to the bottom to find the traces of the foreign language in order to propose in the end a new form just like the claim for piecing together the broken vessel. Translating does not mean making what is strange in the foreign language sound familiar, but rather making one's own language strange until one finds in it, by penetrating its foundations, the forgotten traces of the foreign language. In his well-known "Epistemo-Critical Preface" to the Origin of the German Trauerspiel, Benjamin acknowledges again his naming theory of language, making a statement that has not gone unnoticed, namely, that Adam is not only the father of all men but also the "father of philosophy" (GS-I.1, p. 217) since through the imposition of names, the restoration of the linguistic essence of the idea and the fight against the instrumental value of words lies with him. What should maybe be read here as a watermark is the figure of Adam as the first expression of the ontological difference in language between what is merely ontic, such as losing oneself and sinking into "chatter" (Geschwätz) or into "communicating something", and what is ontological, where naming is understood as communication in the language of each creature and hence, as the very ontological expression of spiritual revelation through language among creatures. As Bolz and van Reijen affirm "language should not-or should not principally be understood as the reporting of thoughts or experiences, but as the form-and this is not meant metaphorically—of all that exists" (Bolz and Reijen 1996, p. 21). The productivity of Benjamin's reading concerning this articulation can also be seen with respect to other problems when, in Goethe's Elective Affinities (1922-1925) the distinction between fallen language and true language returns to literary criticism in order to distinguish between the conditions of an "apparent" and a "true" reconciliation between lovers. Examining the behavior of the characters in Goethe's short story The Wayward Young Neighbours, Benjamin describes the impossibility of reaching true reconciliation between lovers who all the time seem to want to avoid true fight-like the calm before the storm (Pangritz 2000, pp. 778-81). A safe, bourgeois love bond such as the one Goethe seems to offer, in Benjamin's point of view, is a bond that has produced " ... the complete silence of all emotions" (GS-I.1, p. 184) and therefore can only seek apparent reconciliation. True reconciliation, on the contrary, should be able to deal with a mystery: that of love and beauty, divine grounds for "the hope of redemption we still cherish for all the dead" (GS-I.1, p. 200). Later on, in his Erkentnniskritische Vorrede introducing his Ursprung des deutschen Trauerspiels (GS-I.1, pp. 207-37) these initial intuitions are revealed as the scholastic term "treatise" is used to refer "albeit implicitly, to those objects of theology without which truth is inconceivable". Indeed, we are confronted here with a notion that stems directly from his first philosophy of language and nevertheless becomes a theological key with relation to his later philosophy-the Babelic notion of the fall. In the same way that for Benjamin Babelic languages of the Fall, namely the profane languages, admit something as a character of translatability (Übersetzbarkeit) which is constitutive of their linguistic character and prior to their actual translation and revelation through translation, our secular and profane past belonging to historic time admits something of a moment of its recognizability (Augenblick 
seiner Erkenntnisbarkeit) which is constitutive of their historic character. If in both cases existence comes to revelation through language, specially through the Tikkum rescue inherent to the Fall, then the Irrevelation's side of revelation (Cohen-Levinas 2013) as a ruin or as the fogged negative of revelation is the failed side of history that cries out for its redemptive rescue through an inversed theology involved in the profane realm. This is spectrality. At some point we could say here that theology in Benjamin is heretically interwoven with a sort of spectrology, and their common medium is language together as a theological, magic, and cognitive device.

\section{Conclusions}

As we said above, the "invisibility" of theology in Benjamin does not mean the invisibility of its theological marks. On the contrary, the latter are disseminated throughout the entire corpus. Nevertheless, we have proposed here the figure of theology as an "invisible organon", intending to productively decline this device through Benjamin's redemptive criticism.

This was clear through the first thesis of On the Concept of History, where Benjamin prescribes that historical materialism "enlists the services of theology, which today, as we know, is small and ugly and has to keep out of sight" (nicht darf blicken lassen) (GS-I.2, p. 693; SW-4, p. 389). We attached to this plane the Adornian formula of an "inversed theology" (Adorno and Benjamin 1994), which means the reshaping of theology through the profane, like in Kafka's own Haggadah, being an indirect way to imply the theological language in the reading of the historical material content, however in the frame of a rescuing and redemptive horizon. This sort of cryptical and encoded invisibility is well depicted in Benjamin's famous declaration on his relation to theology (PW N7a7; Benjamin 1999, p. 471). By way of comparing theology with ink, and his own thinking with the blotting pad, Benjamin emphasizes that the latter is saturated with the former, but he observes, nevertheless, that "were one go by the blotter, however, nothing of what is written would remain" (nichts, was geschrieben ist, übrig bleiben). Therefore, his standpoint is that whereas the traces of theology indeed fully impregnate his thinking, theology survives in the latter only at the prize of being completely reshaped, like Irving Wohlfahrt's own expression of "Re-Fusing Theology" (Wohlfarth 1986, pp. 3-24). This figure led us to another plane of invisibility which is the one of the Kabbalah. As early as in 1918, in On the Program of the Coming Philosophy (SW-1, pp. 100-10; GS-II.1, pp. 157-71), Benjamin promoted the abandonment of the enlightened mathematical-mechanical conception of knowledge in favor of a linguistic-critical method based on the philosophy of language. But precisely his philosophy of language, developed since 1916 in his essay "On Language as Such and on the Language of Man" (SW-1, pp. 62-74; GS-II.1, pp. 140-57), so important for Benjamin's thought, is rooted both in the scriptural Jewish tradition and in the tradition of the Kabbalah. In the last part of our paper, we then used Benjaminian philosophy of language and Benjaminian idea of translation to complete our sketch on a Benjaminian theological grammar of historical past that we had previously opposed to the Heideggerian idea of historical time as something being extracted out of Dasein's intentionality. It is worth here-in order to conclude- to quote Benjamin himself, coming back in his last period to confront Heidegger precisely on historical time, through a well-known fragment of Das Passagen-Werk:

(Heidegger seeks in vain to rescue history for phenomenology abstractly through "historicity".) [ ... ]. Every present day is determined by the images that are synchronic with it: each "now" is the now of a particular recognizability. In it, truth is charged to the bursting point with time. (This point of explosion, and nothing else, is the death of the intentio, which thus coincides with the birth of authentic historical time, the time of truth.). It is not that what is past casts its light on what is present, or what is present its light on what is past; rather, image is that wherein what has been comes together in a flash with the now to form a constellation. In other words: image is dialectic at standstill. For while the relation of the present to the past is purely temporal, the relation of what has been to the now is dialectical: not temporal in nature but figural <bildlich $>$. Only dialectical images are genuinely historical—that is, not archaic—images. The image that is read-which is to 
say, the image in the now of its recognizability—bears to the highest degree the imprint of the perilous critical moment on which all reading is founded. [PW, N3,1] (Benjamin 1999, pp. 462-63)

Funding: This research was funded partially by CONICT and Project PICT 2014-02968.

Conflicts of Interest: The author declares no conflict of interest.

\section{References}

Abadi, Florencia. 2014. Walter Benjamin: Conocimiento y redención. De Kant al surrealism. Buenos Aires: Miño y Dávila.

Adorno, Theodor. 1973. The Jargon of Authenticity. London: Routledge \& Kegan Paul.

Adorno, Theodor, and Walter Benjamin. 1994. Briefwechsel 1928-1940. Frankfurt am Main: Surkamp Verlag.

Adorno, Theodor, and Gershom Scholem. 1994. The Correspondence of Walter Benjamin 1910-1940. Edited and Annotated by Gershom Scholem and Theodor Adorno. Translated by Manfred R. Jacobson, and Evelyn M. Jacobson. Chicago: The University of Chicago Press.

Agamben, Giorgio. 1978. Infanzia e storia. Bologna: Einaudi.

Arendt, Hannah. 1969. Walter Benjamin: 1892-1940. In Walter Benjamin, Illuminations. New York: Schocken Books, pp. 1-55.

Barash, Jeffrey Andrew. 2003. Martin Heidegger and the Problem of Historical Meaning. New York: Fordham University Press.

Benjamin, Walter. 1972-1991. Gesammelte Schriften. Bände I-VII. Frankfurt am Main: Suhrkamp.

Benjamin, Walter. 1978. Gesammelte Briefe. Herausgeber Gershon Scholem und Theodor Adorno. Frankfurt am Main: Suhrkamp Verlag.

Benjamin, Walter. 1999. The Arcades Project. Translated by Howard Eiland, and Kevin McLaughlin. Cambridge: Belknap Press of Harvard University.

Bielik-Robson, Agata. 2014. Jewish Cryptotheologies of Late Modernity: Philosophical Marranos. New York: Routledge. Bolz, Norbert, and Willem Van Reijen. 1996. Walter Benjamin. Atlantic Highlands: Humanities Press.

Caygill, Howard. 1994. Benjamin, Heidegger and the Destruction of Tradition. In Walter Benjamin's Philosophy. Destruction and Experience. Edited by Benjamin Andrew and Osborne Peter. London: Routledge, pp. 1-31.

Cohen, Hermann. 1924. Jüdische Schriften. Berlin: Schwetschkke \& Sohn.

Cohen-Levinas, Danielle. 2013. Révélation et Irrévélation. Walter Benjamin et Gershom Scholem devant Kafka. In Walter Benjamin. Edited by Patricia Lavelle. Paris: Éditions de L'Herne, pp. 314-25.

Derrida, Jacques. 1994. Force de loi. Paris: Galilée.

Derrida, Jacques. 2002. Fichus. Paris: Galilée.

Echeverría, Bolívar. 1998. La modernidad de lo barroco. Mexico: D.F., Era.

Friedlander, Eli. 2012. Walter Benjamin. A Philosophical Portrait. Cambridge: Harvard University Press.

Habermas, Jünger. 1972. Bewußtmachende oder rettende Kritik. In Zur Aktualität Walter Benjamins. Edited by von Siegried Unseld. Frankfurt am Main: Surhrkamp.

Hartung, Günter. 2001. Jacob Taubes und Walter Benjamin. In Abendländische Eschatologie. Ad Jacob Taubes. Under the Direction of Richard Faber, Evelyne Goodman-Thau and Thomas Macho. Würzburg: Verlag Königshausen \& Neumann.

Heidegger, Martin. 1978. Der Zeitbegriff in der Geschichtswissenschaft. In Martin Heidegger, Gesamtausgabe, Band 1, Frühe Schriften. Frankfurt am Main: Vittorio Klostermann, pp. 357-433, Original published as 1916. Zeitschrift für Philosophie Kritik (Formerly Fichte-Ulricische Zeitschrift). Leipzig: Verlag von C. E. M. Pfeffer, vol. 161, pp. 173-88.

Heidegger, Martin. 2006. Sein und Zeit. Tübingen: Max Niemeyer Verlag.

Heidegger, Martin. 2011. The Concept of Time in the Science of History. In Becoming Heidegger: On the Trail of His Early Occasional Writings, 1910-1927. Edited by Kisiel Theodore and Sheehan Thomas. Seattle: Noesis Press, pp. 60-72.

Kafka, Franz. 2009. Selected Shorter Writings. Translated by Ion Johnston. Nanaimo: Vancouver Island University, Available online: http://johnstoniatexts.x10host.com/kafka/kafkatofc.html (accessed on 8 November 2018). 
Kant, Immanuel. 1922. Idee zu einer allgemeinen Geschichte in weltbürgerlicher Absicht. Edited by Schriften. Berlin: Cassirer. First published 1784.

Kant, Immanuel. 2008. Religion Within the Limits of Reason Alone. New York: Harper One, First published 1793.

Oakes, Guy. 1986. Rickerts's Theory of Historical Knowledge. In The Limits of Concept Formation in Natural Science. A Logical Introduction to the Historical Sciences. Edited by Heinrich Rickert. Cambridge: Cambridge University Press, vols. vii-xxxi.

Pangritz, Andreas. 2000. Theologie. In Benjamins Begriffe. Edited by Erdmut Wizisla and Michael Opitz Herausgegeben. Frankfurt am Main: Suhrkamp, pp. 774-825.

Raulet, Gérard. 2010. Kommentar. In Werke und Nachlaß. Kritische Gesamtausgabe, Über den Begriff der Geschichte. Edited by Gérard Raulet. Berlin: Suhrkamp Verlag, pp. 159-379.

Rickert, Heinrich. 1913. Die Grenzen der naturwissenschaftlichen Begriffsbildung. Tübingen: Mohr, Translated by Guy Oakes. As 1986. The Limits of Concept Formation in Natural Science. Cambridge: Cambridge University Press.

Roca, Deodoro. 1999. Ciencias, maestros y universidades. In Deodoro Roca, el hereje. Edited by N. Kohan. Buenos Aires: Biblos, pp. 99-108. First published 1915.

Roca, Deodoro. 1999. "La juventud argentina de Córdoba a los hombres libres de Sudamérica" ("Manifiesto Liminar de la Reforma Universitaria", June 21 1918). In Deodoro Roca, el hereje. Edited by N. Kohan. Buenos Aires: Biblos, pp. 77-82.

Ryle, Gilbert. 2000. The Concept of Mind. London: Penguin Books.

Sagnol, Marc. 2003. Temps mécanique et temps historique. In Tragique et Tristesse. Walter Benjamin, archéologue de la modernité. Edited by Sagnol Marc. Paris: Les Éditions du Cerf, pp. 35-54.

Scholem, Gershom. 1975. Walter Benjamin: Die Geschichte einer Freundschaft. Frankfurt am Main: Suhrkamp Verlag. Steiner, Uwe. 2000. Kritik. In Benjamins Begriffe. Edited by Erdmut Wizisla and Michael Opitz Herausgegeben. Frankfurt am Main: Suhrkamp, pp. 479-523.

Szondi, Peter. 1961. Hoffnung im Vergangenen. Über Walter Benjamin. Zürich: Neue Zürcher Zeitung, October 8.

Taubes, Jacob. 1993. Die Politische Theologie des Paulus. Munich: Wilhelm Fink Verlag.

Ullmann, Wolfgang. 1992. Walter Benjamin und die jüdische Theologie. In Aber ein Sturm weht vom Paradiese her. Texte zu Walter Benjamin. Edited by Michael Opitz and Erdmut Wizisla. Leipzig: Reclam, pp. 99-101.

Wittgenstein, Ludwig. 1958. Philosophical Investigations. Translated by Gertrude Elizabeth Margaret Anscombe. New York: Basil Blackwell.

Wizisla, Erdmut. 2013. Renoncer à produire du rêve? Le messianisme politique chez Benjamin et Brecht. In Walter Benjamin. Edited by Patricia Lavelle. Paris: Éditions de L'Herne, pp. 303-8.

Wohlfarth, Irving. 1986. Re-Fusing Theology. Some First Responses to Walter Benjamin's Arcades Project. No 39. Second Special Issue on Walter Benjamin. New German Critique, 3-24. [CrossRef]

Wolin, Richard. 1994. Walter Benjamin. An Aesthetic of Redemption. Berkeley: University of California Press. 